\title{
RUSSIAN INDEFINITE PRONOUN kakoj-libo: NON-STANDARD USAGE AND CHANGES IN THE SEMANTICS ${ }^{1}$
}

\author{
YULIA KUVSHINSKAYA \\ National Research University - High School of Economics, Moscow, Russia
}

KUVSHINSKAYA, Yulia: Russian indefinite pronoun kakoj-libo: non-standard usage and changes in the semantics. Journal of Linguistics, 2019, Vol. 70, No 2, pp. 225 -233 .

\begin{abstract}
The paper deals with meaning and use of an indefinite pronoun $k a k o j-$ libo 'any/some' in the modern Russian language. Research based on corpus data revealed non-standard usage of the pronoun kakoj-libo 'any/some'. The paper describes main types of the deviations and evaluates their pragmatic and semantic effect. Finally, tendencies of the change in semantics and use of these pronouns are characterized.
\end{abstract}

Keywords: Russian language, semantics, indefinite pronouns, nonstandard speech, corpus-based approach

\section{INTRODUCTION}

The description of the semantics of the indefinite pronouns is widely considered to be an extremely complicated task [1]. Which is why despite numerous researches, both typological [3] and focused specially on the Russian language ([4], [5]), we still lack understanding in this area.

The studies on the indefinite pronouns have described their semantics through distinguishing features [4] and defined formal and functional types [3]. In the linguists' recent works a list of so called licensed contexts is used to describe these differences ([1], [6]).

This article is dealing with Russian pronouns of the -libo series. In special studies this series has hardly received close attention. In the dictionaries, meaning of such pronouns is usually clarified through references to the pronouns of other series [1]. As a result, the researchers know only a little about the peculiarities of their semantics or the rules of their contemporary usage.

Although the pronouns of the -libo series used to be defined as "bookish" ([4], [2]), in the contemporary Russian language they are widely used in media as well as in the spoken language. For instance, while during 1900-1990 according to the Russian National Corpus (RNC) the pronoun kakoj-libo 'any/a' was used far less

${ }^{1}$ The study was implemented in the framework of the Basic Research Program at the National Research University Higher School of Economics. 
often than kakoj-nibud' 'any/some' or kakoj-to 'some/a sort of' (the ratio for the early 50s is 106,6 ipm (kakoj-libo) to $230.40 \mathrm{ipm}$ (kakoj-nibud') to $824.66 \mathrm{ipm}$ (kakoj-to)), in the modern internet speech, according to RuTenTen, kakoj-libo prevails (89,4 ipm (kakoj-libo) to 59,42 ipm (kakoj-nibud') to 0,39 ipm (kakoj-to)). Besides, the mentioned changes go alongside with deviations from its standard use.

This article aims at describing the main types of the non-standard use of the pronoun kakoj-libo 'any/a'.

The other pronouns of the -libo series (kto-libo - 'anyone', chto-libo 'anything', gde-libo - 'anywhere' etc.) are not taken into consideration, because there are only a few instances of their both standard and non-standard usages in the evidence of the students' texts.

While analyzing a non-standard use we cling to the concept that considers speech errors as a source of more profound knowledge of changes in language. Linguistics on the whole is very interested in a "negative" language evidence (see [8]), however only after the A. Frei's work it turned into a special subject of study. Later the idea of "grammar of errors" resulted in a range of researches dealing with speech deviations, slips of the tongue etc. ([13], [14], [15], [16], [20]) and encouraged study of the SLA, works on the oral language and so on ([9], [10], [11], [12]).

The non-standard cases of use of the pronouns were examined on the evidence of two corpora: a corpus of Russian students' texts (CORST, 54 instances) and the NRC (123 instances). The students' texts have revealed deviations in use of the pronoun kakoj-libo 'any/a'. Then we questioned their origins using the RNC's data, especially for electronic communication, which means the most free speech, to find out if these evidence a global tendency or just mistakes.

Under deviations we understand a wide range of contexts, starting with examples of obvious violation of the rules and ending with examples that are grammatically acceptable, but demonstrate an imperfect communicative choice and illustrate the ongoing processes.

We defined instances with kakoj-libo 'any/a' as cases of deviation basing on the description of the licensed contexts ([6], [3]) and using an introspective method along with the results of a written interview of 15 adult native speakers of different occupation and age. An interview was carried out in two steps: 1) the interviewees appreciated the instances, which are mentioned in this article, mixed with the sentences, acting as fillers 2) the interviewees compared the instances from this article with the edited sentences, where the pronoun kakoj-libo 'any/a' had been substituted with another word (for an example see (9) or (10a, 11a)).

The interview revealed that even the native speakers do not fully comprehend the semantics of an indefinite pronoun, find the bookish style and the indefinite meaning unclear and objectionable, but preferable compared to the direct negation. Many (except professional editors and translators) consider non-standard usages of kakoj-libo 'any/a' agreeing with a noun in singular in an affirmative context 
acceptable (examples 3, 7, 9 below). During the second step the native speakers mostly characterized instances with kakoj-libo, non-standard from our point of view, as inappropriate or unacceptable at all, preferring the edited examples.

\section{NON-STANDARD USE OF THE INDEFINITE PRONOUN kakoj-libo}

Now we will describe the main types of non-standard use of $k-l$, the semantic and pragmatic effects and probable causes of such usage.

\subsection{The use in an unlicensed (affirmative etc.) context}

(2) Yego glavnaya ideya zaklyuchalas' $v$ predlozhenii provodit' eksperimenty $i$ issledovaniya, uznavaya informatsiyu o vozrastnom, professional'nom, territorial'nom i dr. statusakh respondenta [18]. 'His main idea was an offer to carry out some kind of experiments and researches, finding out information about the age, professional, territorial and other state of the respondent'.

(3) Takim obrazom, dlya togo chtoby zaimstvovaniya garmonichno sosushchestvovali s iskonnymi slovami, prisushchimi kakomu-libo yazyku, neobkhodimo razvit' obshcheye prezreniye lyudey $k$ neumestnomu, chrezmernomu upotrebleniyu [18]. 'Thus, for borrowings to coexist harmoniously with the original words inherent in some language, it is necessary to develop people's general contempt for inappropriate, excessive use of foreign words'.

(4) Tol'ko ne navyazyvat', a prosto iskrenne delit'sya toy pol'zoy, kotoruyu vy sami izvlekli iz kakikh-libo istochnikov. [17]. 'Just do not impose, but just sincerely share the benefits that you yourself have gained from some sources'.

In these instances $k-l$ is included in affirmative sentences. Besides, in $(3,4)$ the noun phrase refers to indefinite but real objects, and such use is not typical for $k-l$. There is no doubt that $k-l$ makes these sentences more (probably too) formal. In the example (2) the pronoun can be removed without any loss in meaning, i.e. $k-l$ is redundant; in the examples (3-4) we cannot removed the pronoun without replacing it with another quantifier with a specific meaning of a nonrandom, definitely real object of the set that can be chosen either by the speaker or by the actor (opredelennyy 'definite', konkretnyy 'certain').

It seems that such usage occurs under the influence of special contexts found in dictionaries, instructions or legislative texts. In such texts $k-l$ is used in the meaning of a variable, a gap that should be filled in certain situations:

(5) Dno-Nizhnyaya stenka, osnovaniye sosuda, sudna, kakogo-l. vmestilishcha. [1]. 'Bottom - A wall below, a base of a vessel or some container'.

(6) Litsa, uchastvuyushchiye $v$ dele, ikh predstaviteli vprave khodataystvovat' ob oglashenii kakoj-libo chasti protokola... [Grazhdanskiy protsessual'nyy kodeks Rossiyskoy Federatsii (2002)] [17]. 'Persons, who participate in the deal, and their representatives are allowed to demand announcing any part of the report'. 
For such a use of $k-l$, both standard and non-standard, the idea of a potential plurality and variety of the objects and the idea of a choice are very important.

\subsection{The use in a licensed context but without taking into account the semantics of the potential set}

(7) Prichinoy [strakha - YU.K.] mozhet byt' kakaya-libo tragediya ili bedstvennoye polozheniye. [18]. 'The cause [for fear - Yu.K.] can be any tragedy or tribulation'.

(8) Yesli vy vnosite kakoj-libo vklad $v$ mirovuyu kul'turu, to on sokhranitsya $v$ pamyati lyudey imenno blagodarya memam. [18]. 'If you make any contribution to the world culture, it will remain in people's memory thanks to memes'.

These sentences are non-standard because the noun on which the pronoun depends refers to a class of objects, its meaning is generic and does not express multiplicity. In (8) $k$-l is used in an idiom, but the meaning of the idiom allows no diversity.

In such contexts $k-l$ that defines a noun in singular with a generic meaning actually acts as an indefinite article. Paducheva notes that an indefinite pronoun phrase tot ili inoj can sometimes play the role of an indefinite article. This usage is standard for the phrase tot ili inoj [6] but not for $k-l$.

The instance (9) clearly demonstrates the deviation caused by misunderstanding both the quantifier nature of the pronoun kakoj-libo 'any/a' and the semantics of the set of similar objects:

(9) Seychas my mozhem nablyudat' tendentsiyu k sozdaniyu osobogo molodezhnogo slenga, upotreblyayushchegosya isklyuchitel'no v kakom-libo gorode ili oblasti ... [18]. 'Now we can observe a tendency to create a special youth slang, used exclusively in some city or a region'.

The phrase isklyuchitel'no $v$ kakom-libo means the only possible object, but the appropriate meaning is "one undefined object". This meaning should be expressed by the phrase $v$ odnom kakom-libo.

\subsection{The use in negative but not expressive contexts instead of negative pronoun nikakoj 'no, none, any'}

(10) Yesli Vy chustvuyete chto ona otkryta i u neyo net kakikh-libo problem, to rasslabtes'. [17], saved source spelling]. 'If you feel that she is open and does not have any problems, then relax'.

(11) Zametim, chto Fransua Olland ne predstavlyayet kakikh-libo argumentov $v$ pol'zu utverzhdeniya, chto ul 'trapravyye ne dolzhny proyti vo vtoroy tur. [18]. 'Let us note that Francois Hollande does not provide any arguments in favor of the assertion that the ultra-right should not enter the second round'.

(12) K sozhaleniyu, diakhronicheskiy analiz semantiki vsey vyborki ne pokazal kakoj-libo dinamiki $v$ izmeneniyakh semantiki $-z a$ isklyucheniyem pary-troyki 
primerov s nesnyatoy omonimiyey [18]. 'Unfortunately, the diachronic analysis of the semantics of the entire sample did not show any dynamics in the development of semantics with the exception of a couple of examples with unmodified homonymy'.

The use in a negative context is normal for $k-l$ [2]. The standard use of the pronoun we see in the examples (13-15).

(13) Oblasti, zanyatyye slavyanami v rimskoye vremya (II-IV vv. n. e.), ne imeli kakikh-libo yestestvennykh rubezhey. Tuda neodnokratno vtorgalis' s zapada razlichnyye plemena germantsev [17]. 'The areas occupied by the Slavs in the Roman time (II-IV centuries), did not have any natural boundaries. Various tribes of Germans repeatedly invaded this area from the west'.

(14) Terrorizm nel'zya assotsiirovat's kakoj-libo religiyey, etnicheskoy gruppoy ili geograficheskim rayonom, i u nego net nikakogo opravdaniya [17]. 'Terrorism cannot be associated with any religion, ethnic group or geographical area, and it has no excuse'.

We believe that the non-standard use of $k-l$ in $(10-12)$ can be explained by the fact that these example refer to homogeneous objects, which mean no variety $(10$, $11)$, or to the same phenomenon (12). The homogeneity of the objects indicated by a noun phrase with $k-l$ is important since the contexts imply opposition of these objects to the others. In (10) the psychological problems are opposed to the openness to communication, in (11) the arguments in favor of the statement are opposed to potential objections. As for $k-l$, it introduces the notion of diversity of similar objects that does not correspond with the idea of the sentence.

In contrast, in the standard sentences (13-14) an author speaks about a potentially diverse set of objects: about natural borders of different types (13), different religions, ethnic groups etc. (14). The meaning of diversity should be considered peculiar for $k-l$ which is etymologically a pronoun of a free choice [3]. The non-standard sentences can be improved by introducing a restrictive definition to the noun phrase:

(10a) Yesli Vy chustvuyete chto ona otkryta i u neyo net kakikh-libo cer'yeznykh problem, to rasslabtes'. 'If you feel that she is open and does not have any serious problems, then relax'.

(11a) Zametim, chto Fransua Olland ne predstavlyayet kakikh-libo vesomykh argumentov v pol'zu utverzhdeniya, chto ul'trapravyye ne dolzhny proyti vo vtoroy tur. 'Let us note that François Hollande does not represent any strong arguments in favor of the assertion...'.

(12a) K sozhaleniyu, diakhronicheskiy analiz semantiki vsey vyborki ne pokazal kakoj-libo zametnoy dinamiki $v$ izmeneniyakh semantiki. '...the diachronic analysis of the semantics of the entire sample did not show any notable dynamics in the development of semantics'.

Restrictive definitions designate a part of a set that has a certain feature, which is named by the definition. These definitions thereby oppose the selected subset to 
the rest part of the set which do not have this feature. Thus, the noun phrase that includes $k$ - $l$ denotes the set of similar, but different objects.

As for the reasons for the use of $k-l$ in these contexts, the main one is the speaker's intention to indicate the possibility that other objects exist. In other words, in example (10) by using $k-l$ the author introduces an implication that there could be different problems; in (11) he/she implies that arguments were expected; in (12) the student regrets the lack of dynamics that could have been observed (this conclusion comes from the extra-language context of the example). Thus, it appears that the meaning of an object from a potentially existing set, intrinsic to $k-l$, is used here to indicate an unrealized opportunity.

At the same time, this deviation cannot be considered a rude violation of the norm, since the basic conditions for the use of pronouns are met. We consider such cases as examples of not the best communicative choice, as poor understanding of the semantics of the context and the word. Nevertheless, Paducheva believes that in many instances not the indefinite pronoun, but a negative pronoun is preferable [2].

\subsection{The expressive use of the indefinite pronoun kakoj-libo}

As Haspelmat shows, free choice and negative polarity pronouns can be used to express the meaning of the lower level of the pragmatic scale, in Fauconnier' terms [19; 3, p. 116-117]: "at least one X (not) exists ... that corresponds with...".

Ward also speaks about the "emphatic negative function of -libo forms" [5, p. 466].

As the corpus data shows, $k-l$ is indeed used in the emphatic function, expressing the meaning of the lower level of the pragmatic scale. But such expressive use of the pronouns is often accompanied by deviations from the standard:

(15) Blagodarya takomu podkhodu, izuchayushchiye russkiy kak inostrannyy, dazhe pri otsutstvii kakogo-libo lingvisticheskogo obrazovaniya mogut bez osobykh usiliy chitat' nastoyashchiye slovarnyye stat' $i$ [18]. 'Thanks to this approach, those, who learn Russian as foreign language, even without any linguistic education, can read real dictionary articles effortless'.

(16) Da lyudey prosto tak sazhayut, bez kakikh-libo krazh. [17]. 'But people get imprisoned just so, without any thefts'.

In both examples (15-16) the meaning of the lower level of the pragmatic scale is applied to an inappropriate object. Indeed, in these contexts lingvisticheskoye obrazovaniye 'the linguistic education' (15), krazha 'theft' (16) are generic terms and do not allow scaling.

\section{THE SEMANTIC FEATURES AND THE USAGE OF THE INDEFINITE PRONOUN kakoj-libo}

Before defining the types of deviation in use of the pronoun kakoj-libo 'any/a'; further $k-l)$ we will try to describe its standard features. 


\subsection{The semantic features}

E. V. Paducheva, summarizing results of her research [2], qualifies this pronoun as non-referent, i.e. the pronoun expresses reference to an object of the set that is not identified in reality (Veyrenc classifies these pronouns as virtual) [4].

(1) ... YA ne raspolagala kakimi-libo dannymi o svoikh budushchikh sobesednikakh. [17]. 'I did not have any information about my future interlocutors'.

Following M. Haspelmath [3], she defines this pronoun as a quantifier that expresses an existential but not universal meaning, i.e. it distinguishes one of the objects of a set [2].

Paducheva argues in terms of the logical approach to semantics that a presumption of nonexistence of the set is necessary when using $k-l$. We understand this statement so that the noun phrase containing $k-l$ refers to an indefinite object from a potentially existing set. For instance, the sentence (1) speaks about some objects, possibly in existence, but they are unknown to the speaker, so it is impossible to say if these objects truly exist.

Paducheva as well as Haspelmath considers $k-l$ to be a pronoun with negative polarity. Haspelmath notes that "-libo indefinites were originally free-choice indefinites" and although they have lost this function, they still have the comparative function [3, p. 89].

The dictionary definition of this pronoun (through the pronoun kakoj-nibud' 'any/some' also shows that $k-l$ as well as kakoj-nibud'means a choice of one element from a range of similar ones: "1. Tot ili inoy, lyuboy iz ryada podobnykh" 'One or another, any of a number of similar' [1].

\subsection{The licensed contexts}

Paducheva identifies several typical contexts that make the use of Russian negative polarity pronouns including kakoj-nibud' 'any/some' possible [2].

Negative contexts:

- direct negation,

- contexts with a negative verb (lishit' 'deprive', otsutstvovat' 'be absent'), preposition (bez 'without', protiv 'against').

Non-affirmative contexts:

- conditional clause

- interrogative clause

- comparative construction

- verbal participle, especially with modality or repeating action

Paducheva points out that Russian pronouns of negative polarity are not licensed in the context with universal quantification as well as under a phrasal stress [2]. 


\section{THE DISTRIBUTION OF THE TYPES OF DEVIATIONS IN SPEECH OF THE STUDENTS AND THE ADULT NATIVE SPEAKERS}

The non-standard type of use of the indefinite pronoun kakoj-libo 'any/a' in which the pronoun acts as an indefinite article in the context that expresses generic quantification is frequent in students' speech, but rarely occurs in the online speech produced by the adult native speakers.

The expressive use of $k-l$ is more common in online speech and is not very frequent in students' written language. Obviously, the latter is due to the bookish, often scientific genres of these texts which are not supposed to be expressive.

\section{CONCLUSION}

Thus, we have considered the main types of deviations from the standard use of the pronoun kakoj-libo 'any/a' based on the corpus data representing the students' written language and the Internet speech of the adult native speakers.

The deviations in the use of $k-l$ seem to be caused by:

1) The lack of understanding of the quantifier nature of a pronoun. The authors of the examples confuse the values of a discrete set and the values of a class, existential and universal quantification.

2) An intention to make the speech more official (in some contexts).

3) An intention to make the speech more expressive (in other contexts).

At the same time, it seems that these deviations came from the intention to express meanings that are either untypical for the pronoun in standard speech or limited to special contexts:

- A gap that is potentially filled in when a statement is applied to a specific situation (a consequence of the etymological meaning of free choice).

- The diversity of the elements of the set. It seems that this is also a consequence of the etymological significance of free choice. In such contexts $k$ - $l$ is synonymous to the adjective different. This meaning enables the speaker to implement a variety of pragmatic strategies.

The analysis of the non-standard use of the pronoun kakoj-libo 'any/a' reveals, on the one hand, difficulty in implementing the categories and strategies of written speech (quantifier semantics, formal style, expressiveness), and on the other hand, the ongoing search for new ways to express meaning in the modern language, including ideas of diversity, quantification and expressiveness.

\section{References}

[1] Evgenieva A. P. (ed.). Slovar' russkogo yazyka: V 4-kh tomakh. (1999). $4^{\text {th }}$ edition. Moscow, Russkiy yazyk; Poligrafresursy. 
[2] Paducheva, E. V. (2015). Mestoimeniya otritsatel'noy polyarnosti. In Russkaya korpusnaya grammatika. Accessible at: http: / / rusgram.ru/index

[3] Haspelmath, M. (1997). Indefinite Pronouns. Oxford, Clarendon Press.

[4] Veyrenc J. (1964). Kto-nibud'et kto-libo formes concurentes? Revue des études Slaves, 40. pages 224-233.

[5] Ward, D. (1977). On Indefinite Pronouns in Russian. The Slavonic and East European Review, 55(4), pages 444-469.

[6] Paduceva, E. V. (2017). Oborot tot ili inoy. In Russkaya korpusnaya grammatika. Accessible at: http://rusgram.ru/index

[7] Efremova, T. F. (2000). New dictionary of the Russian language. Explanatory and wordformative. V 2 tomakh. Moscow, Russkiy yazyk.

[8] Shcherba L.V. (1931). O troyakom aspekte yazykovykh yavleniy i ob eksperimente v yazyke soznaniya. Pamyati uchitelya I. A. Boduena de Kurtene. Izvestiya AN SSSR, 1, pages 113-129. Accessible at: http://www.ruthenia.ru/apr/textes/ sherba/sherba3.htm

[9] Vakhtin, N., Mustajoki, A., and Protassova, E. (2010). Russkie jazyki. In Instrumentarium of linguistics: Sociolinguistic approaches to non-standard Russian. Helsinki, Yliopistopaino (Slavica Helsingiensia; vol. 40). pages 5-16.

[10] Zemskaja, E. A. (ed.). (2001). Jazyk russkogo zarubežja: obščie process i rečevye portrety. Vena.

[11] Bogdanova-Beglaryan N. V. (2015). Agressivnyy uzus - ili evolyutsiya yazykovoy normy? Verkhnevolzhskiy filologicheskiy vestnik, pages 25-31.

[12] Lapteva, O. A. (1990). Živaja russkaja reč s teleekrana. Seged.

[13] Frei H. (2006). Grammatika oshibok. Moscow, Komkniga.

[14] Rusakova, M. V. (2013). Elementy antropotsentricheskoy grammatiki russkogo yazyka. Moskow, Yazyki slavyanskikh kul'tur.

[15] Rahilina, E. V. 2014. Grammatika ošibok: v poiskah konstant. In Jazyk. Konstanty. Peremennye, pages 87-95. Cankt-Peterburg. Aleteyya.

[16] Zevakhina, N. A., and Dzhakupova, S. S. (2015). Corpus of Russian student texts: design and prospects. In Materialy 21-y Mezhdunarodnoy konferentsii po komp'yuternoy lingvistike "Dialog". Moscow.

[17] Russian National Corpus. Accessible at: http://www.ruscorpora.ru/ index.html.

[18] Corpus of Russian student texts. Accessible at: http://web-corpora.net/ learner_corpus.

[19] Fauconnier, G. (1975). Pragmatic scales and logical structures. Linguistic Inquiry 6, pages 353-375.

[20] Fromkin V. (1973). Speech errors as linguistic evidence. The Hague, Mouton. 